\title{
Lise Öğrencilerinin Mesleki Kararsızlıklarını Açıklamada Kariyer Denetim Odağı İle Meslek Seçimine İlişkin Akılcı Olmayan İnançların Rolü ${ }^{1}$
}

DOI: $10.26466 /$ opus. 800873

\author{
* \\ Niğmet Yılmaz* - Ahmet Bedel ** \\ * Uzman Psikolojik Danışman, Milli Eğitim Bakanlığı, Sakarya/Türkiye \\ E-Posta: nigmet.ylmaz@gmail.com \\ ORCID: $\quad 0000-0002-7113-5127$ \\ **Doç. Dr., Maltepe Üniversitesi Eğitim Fakültesi İstanbul/Türkiye \\ E-Posta: ahmetbedel@maltepe.edu.tr \\ ORCID: $\quad 0000-0003-4215-9290$
}

\begin{abstract}
Öz
$B u$ araştırmanın amacı, lise öğrencilerinin mesleki kararsıllılarının, kariyer denetim odaklarının ve meslek seçimine ilişkin akılcı olmayan inançlarının cinsiyete göre farklılaşı farklılaşmadığını belirlemek ayrıca mesleki kararsızlıklarını açıklamada kariyer denetim odağı ile meslek seçimine iliş̧in akılcı olmayan inançların rolünü belirlemektir. Bu amaçla 672 lise öğrencisinden Mesleki Karar Envanteri (MKE), Kariyer Denetim Odağı Ölçeği (KDOÖ), Meslek Seçimine İlişkin Akılcı Olmayan İnançlar Ölçeği (MSIAOIÖ) aracılı̆̆ıyla veri toplanmıştır. Araştırmada Bağımsız Ortalamalar T-Testi, Pearson Korelasyon Analizi, Çoklu Hiyerarşik Regresyon Analizi kullanılmıştır. Araştırmada, öğrencilerin mesleki kararsızlık puanlarının cinsiyete göre farklılaşmadığı, kariyer denetim odağı ve meslek seçimine ilişkin akılcı olmayan inançlar puanlarının cinsiyetlere göre anlamlı şekilde farklılaştığı görü̈lmüş̧ür. Öğrencilerin, mesleki kararsızlıkları ile kariyer denetim odağı alt boyutları ve meslek seçimine ilişkin akılcı olmayan inançlar alt boyutları arasında anlamlı ilişkilerin olduğu görülmüştür. Araştırmada, yordayan değişkenlerin mesleki kararsızlığın toplam varyansının \%30'unu açıkladığı saptanmıştır.
\end{abstract}

Anahtar Kelimeler: Lise öğrencileri, mesleki kararsızlık, kariyer denetim odağı, meslek seçimine ilişkin akılcı olmayan inançlar.

\footnotetext{
${ }^{1}$ Bu çalışma, 2019 yılında Maltepe Üniversitesi Sosyal Bilimler Enstitüsünde Niğmet Yılmaz tarafından yapılan Doç. Dr. Ahmet BEDEL danışmanlığında yürütülen yüksek lisans tezinden üretilmiştir.
}

OPUS ( ) Uluslararası Toplum Araştırmaları Dergisi-International Journal of Society Researches ISSN:2528-9527 E-ISSN : 2528-9535

http://opusjournal.net 


\title{
The Role of Career Locus of Control and Irrational Beliefs About Career Choice in Explaining the Career Indecision of High School Students
}

\begin{abstract}
The aim of this research is to determine possible difference between genders of career indecision of high school students, career locus of control and irrational beliefs about career choice, furthermore to determine the role of career locus of control and irrational beliefs about career choice in explaining career indecision. For this reason, data were collected from 672 high school students with Career Decision Inventory, Career Locus of Control Scale (CLCS), and Irrational Beliefs in Career Choices of High School Students (SIBCC-HS). Independent Samples T-test, Pearson Product-Moment Correlation, Hierarchical Linear Regression Analysis were used in this research. In the study, it was observed that the career indecision scores of the students did not differ according to gender, and the scores of career locus of control and irrational beliefs about career choice differ significantly according to gender. It was observed that there were significant relationships between students' professional indecision and career locus of control sub-dimensions and irrational beliefs about career choice sub-dimensions. In the study, it was determined that the predictive variables explain $30 \%$ of the total variance of career indecision.
\end{abstract}

Keywords: High school students, career indecision, the career locus of control, irrational beliefs relating to the career choice 


\section{Giriş}

İnsan hayatında önemli bir yere sahip olan ergenlik döneminin önemli gelişim görevlerinden biri meslek seçimidir. Ergenlik dönemi, bireyin bir taraftan kendi kişisel kimliğini kazanmaya çalıştı̆̆ bir taraftan da meslek seçme faliyetlerine devam ettiği bir dönem olarak görülmektedir (Santrock, 2012). Bireyin yaşamında 14-18 yaş aralığına denk gelen bu dönem; mesleklere ilişkin daha net fikirler kazandığı ve kariyer alternatifleri arasında seçim yaptı̆̆ bir dönemdir (Siyez, 2019). Bu dönemde bireyler kendi ilgi, yetenek ve değerlerini keşfederken aynı zamanda da belirsizlikleri, kararsızlıkları, duygusal çalkantıları ve çatışmaları yoğun olarak yaşamaktadır (Siyez, 2019). Bu çalkantılı döneminde bireyden kendisi için en uygun mesleği seçmesi beklenmektedir. Eğer bu dönemde birey, mesleğini seçmesi gerekirken kendisi için uygun bir mesleği seçemezse, sık sık karar değiştirirse ve kararını veremezse mesleki kararsızlık yaşıyor demektir (Kuzgun, 2017). Mesleki kararsızlık; bireyin bir mesleğe karar verme derecesini ifade eder (Xu ve Bhang, 2019).

Kuzgun ve Bacanlı (2011)' ya göre; bireyler mesleki gelişim görevini yerine getirmediğinde gelişimsel mesleki kararsızlık yaşamaktadır. Bazı araştırmacılara göre; gelişimsel kararsızlık, gelişimin doğal bir parçasıdır (Hartman, Fuqua ve Hartman, 1983). Araştırmacılar bireyin gelişimsel kararsızlı̆̆ının; meslekler ve kendileri hakkında bilgi eksikliğinden kaynaklandığını (Aydemir, 2017; Çakır, 2003; Çapçı, 2017; Çınar, 2011; Kelly ve Lee, 2000; Kırdök, 2010; Kuzgun ve Bacanl1, 2011; Ladany, Melıncoff, Constantine ve Love, 1997) ve bireylere mesleki kararsızlıklarını azaltıcı programların uygulanması ile kararsızlıklarının azaltıldığını belirtmektedir (Çakır, 2003; Çınar, 2011; Kırdök, 2010; Şeker ve Kaya, 2019). Ayrıca araştırmacılar mesleki kararsızlığın; bireylerin yetenek ve ilgilerinin ayrışmaması (Kuzgun, 2017), zayıf kimlik gelişimi, ana-baba tutumu, denetim odağının dıştan algılanması, kişilik bozukluğu, kaygı (Çapçı, 2017; Hamamcı ve Hamurlu, 2005; Hartman, Fuqua ve Hartman, 1983; McAuliffe,1991; Yazıcıoğlu, 2008), nevrotik kişilik (Kırdök ve Kayadibi, 2018), mesleki karar verme öz yetkinliği (Öztemel, 2012; Xu ve Tracey, 2014), aile etkisi ve kariyer kaygısı (Çınar, 2011; Yılmaz ve Gündüz, 2018), bireylerin yaşam amaçlanı ve pozitiflik düzeyleri (Alkal, Korkmaz ve Akça, 2018), e-sporla ilgilenip ilgilenmeme durumu (Kocadağ, 2019), stratejik başaçıkma yöntemleri (Liphits-Braziler, Tatar ve Gati, 2017) gibi nedenlerden de yaşanabileceğini belirtmektedir. 
Bireyler, yaptığı eylemlerin sonuçlarının hangisinin kendinden, hangisinin dışarıdan kaynaklandığını anlamak ister (Şeker, 2013). Eğer birey meslek seçim eyleminin sonuçlarının kendi kontrolünde olduğunu düşünüyorsa iç kariyer denetim odağına, birey kendi meslek seçimi ile ilgili eylemlerinin sonuçlarının kendinin dışındaki faktörlerde (çaresizlik, şans, güçlü diğerleri) olduğunu düşünüyorsa dış kariyer denetim odağına sahiptir (Millar ve Shevlin, 2007). Birey, gelecekteki kariyeri ile ilgili başarılarının kendinden kaynaklandığını düşünürse mesleki karar verme sürecini daha sağlıklı şekilde geçirir (Millar ve Shevlin, 2007). Literatürde bireylerin meslek seçim kararlarında kariyer denetim odağının etkisinin olup olmadığının incelendiği araştırmalar az olmasına rağmen; Hirschi (2010) yaptığı çalışmada öğrencilerin lise seçimi ve meslek seçiminde şans faktörüne inandıklarını tespit etmiştir. Şeker (2013) araştırmasında mesleki karar verme yetkinliği arttıkça bireylerin iç denetiminin de arttığını tespit etmiştir. Guan, Wang, Dong, Liu, Zhang, Zhou ve Liu (2012) Çinli çalışan bireyler üzerinde geliştirdikleri kariyer denetim odağı ölçeğinin nesnel ve öznel kariyer başarısını olumlu şekilde açıkladığını tespit etmişlerdir. Aynı zamanda Kim ve Kim (2017) bir kariyer hazırlama programını üniversiteli öğrenciler üzerinde uygulamış ve öğrencilerin iç kontrol odaklarında artıs gözlemlemiştir. Bununla birlikte diğer araştırmacılar farklı değişkenlerle de kariyer denetim odağının birey üzerindeki etkisini incelemişlerdir. Araştırmacılar kariyer denetim odağını; cinsiyet, sınıf düzeyi, okul türü, toplumsal cinsiyet algısı, bireyin kendini başarılı görüp görmemesi, farkındalık, ırk, ergen bireyin engelli olma durumu (Kantaş, Güldü ve Kart, 2018; Perry, Liu ve Griffein, 2011; Pham ve Murray, 2019; Seymenler ve Siyez, 2016; Şeker, 2013) gibi değişkenlerle de ilişkisini incelemişlerdir.

Bireylerin mesleki karar verme becerisini anlamak için, aynı zamanda; onların algılarının nasıl oluştuğunu, meslek kararını nasıl aldığını ve nasıl uyguladığını bilmek gerekir (Amudson, 1995). Birey doğduğu andan itibaren dış dünya ile girdiği etkileşim sonucunda kendine, dünyaya, çevreye dair genellemelerde bulunur, bu genellemeleri inanç sistemini oluşturur ve bu inanç sistemine göre de karar alır (Özyürek, 2012). Bu bağlamda bireylerin akılcı olan ve akılcı olmayan inançları vardır ve akılcı olmayan inançlar bireylerin problem yaşamasına sebep olur (Akın, 2014). Bireylerin inanç sistemi, hayatını etkilediği gibi meslek seçimlerini de etkilemektedir. Elliott (1995)'a göre; insanın bulunduğu çevre, aile, medya "-meli, -malı" dediğimiz içsel eleştirici 
olan düşünce tarzının gelişmesine sebep olur, bu sebeple birey meslek seçimini yaparken iç sesi onu eleştirebilir ve bireyin doğru karar vermesini engelleyebilir. Dolayısıyla, akılcı olmayan mesleki inançlar; insanların meslek seçimi ile ilgili amaçlarının gerçekleşmesine engel olan duygu ve düşünceleridir (Corbishley ve Yost, 1989). Elliott (1995) akılcı olmayan meslek inançlarının bireyde güvensizlik, özgüven eksikliği, akademik yetersizlik ve erteleme gibi durumlara yol açacağın belirtir. Walsh ve Tampson (1995) ise, akılcı olmayan kariyer inançlarının, bireylerin öğrenimini engelleyerek kendiyle ilgili kariyerlerini ihmal ettiğini belirtir. Yapılan araştırmalar mesleki kararsızlık üzerinde kariyer inançlarının etkili olduğunu göstermektedir(Akkoç, 2012b; Bacanl1, 2012; Enright,1996; Hamamcı ve Çoban, 2007; Kırdök, 2010; Peng ve Herr, 2000; Yaman, 2014). Literatürde, kariyer kararında meslek seçimine ilişkin akılcı olmayan inançların etkili olduğu, mesleki karar verme ile ilgili uygulanan programların bireylerin akılcı olmayan meslek inançlarını azalttığı belirtilmektedir (Hechtlinger, Levin ve Gati, 2017; Kırdök, 2010; Peng ve Herr, 2000). Aynı zamanda bazı araştırmacılar meslek seçimine ilişkin akılcı olmayan inançların cinsiyet, sınıf düzeyi, okul türü (Alver ve Kutluca, 2019; Akkoç, 2012a; Aydemir, 2017; Çapan ve Owen, 2018; Dimakakou, Argyropoulou, Drosos ve Terzaki, 2012; Kaur ve Raji, 2017; Kepir, 2011; Owen Çapan, 2017; Özkamall, Cesuroğlu, Hamamcı, Buğa ve Çekiç, 2014; Savoly ve Owen, 2015; Ulu, 2007) gibi değişkenlerle de ilişkisi olduğunu belirtir. Literatürde meslek seçimine ilişkin akılcı olmayan inançların; akademik başarl, yaş, mesleki olgunluk, umut, eğitim durumu, üniversitede seçmeyi düşündükleri alan, fiziksel engel durumu, kültürel uyum düzeyi, sosyoekonomik durum, ebeveynlerin eğitim durumu, göçmen statüsü, ergenlerin odak noktası, ergenlerin aile çevresine uyumu (Alver ve Kutluca, 2019; Akkoç, 2012b; Arulmani, Laar ve Easton, 2003; Bacanl1, 2012; Dimakakou ve diğerleri, 2012; Enright, 1996; Kaur ve Raji, 2017; Kepir, 2011; Mahadevan, 2002, Owen ve Çapan, 2017; Özkamalı ve diğerleri, 2014; Savoly ve Owen, 2015; Schnorr ve Ware, 2001) gibi değişkenlerle de ilişkisi incelenmiştir.

Birey sosyal bir varlık olduğu için; tüm öğrenimlerini, seçimlerini, duygu ve düşüncelerini bu sosyal ortamdan etkilenerek şekillendirmektedir. Bireyin mesleğini seçmek zorunda olduğu ergenlik döneminde; bireyin kendini yeterince tanımaması, dış çevrenin etkisi, eğitim fırsatları, eğitim koşulları ve bireyin kendi kariyer seçimine dair olumsuz inançları sebebiyle meslek seçi- 
minde kararsızlık yaşayabileceği düşünülmektedir. Literatürde yapılan çalışmalar incelendiğinde, insan hayatında büyük öneme sahip olan meslek seçiminde yaşanan mesleki kararsızlık düzeylerinin kariyer denetim odaklarından etkilenip etkilenmediği ile igilli çalışmaların sınırlı olduğu görülmüştür. Bununla birlikte ergenlik dönemindeki bireylerin meslek seçiminde yaşadıkları kararsızlığın, kariyer inançları ile ilişkisine bakıldığı çalışmalarında sınırlı olduğu görülmektedir. Bu sınırlı araştırmalardan birini yapan Herring (1990), mesleki bilgi eksiklerinin ve olumsuz kariyer gelişiminin meslek seçimine ilişkin akılcı olmayan inançlar sebebiyle olduğunu belirtir. Aynı zamanda diğer yapılan araştırmaların sonucunda; kariyer gelişim süreci içinde bireylerin meslek seçimine ilişkin akılcı olmayan inançlarının mesleki mitlerinin gelişmesine sebep olduğu ve buna göre meslek seçimini gerçekleştirdiğini tespit etmişlerdir (Herring, 1990; Lewis ve Gilhausen, 1981). Lise dönemi mesleki kararların alındığı bir dönem olduğundan; yapılan araştırma ile öğrencilerin meslek seçim kararsızlığına etki edebileceği düşünülen faktörlerin tespitinin yapılmasının, öğrencilere sunulacak kariyer danışmanlığı hizmetlerine katkı sağlayacağı düşünülmektedir. Bu sebeple bu çalışmanın amacı; lise öğrencilerinin mesleki kararsızlıklarının, kariyer denetim odaklarının (iç ve dış denetim odağı) ve meslek seçimine ilişkin akılcı olmayan inançlarının cinsiyetlerine göre farklılaşıp farklılaşmadığını belirlemek, bu değişkenler arasındaki ilişkiyi incelemek, kariyer denetim odağının ve meslek seçimine ilişkin akılcı olmayan inançların mesleki kararsızlığı ne düzeyde yordadığını tespit etmektir.

\section{Yöntem}

\section{Çalışma Grubu}

Araştırma genel tarama modeli olan ilişkisel tarama modeline uygun olarak gerçekleştirilmiştir (Karasar, 2016). Araştırmanın çalışma grubunu, 2018-2019 eğitim öğretim yılında Sakarya'nın Akyazı ilçesindeki 672 ortaöğretim öğrencisi oluşturmaktadır. Akyazı'daki öğrencilerin; 137'si (\%20.4) 9. sınıfa, 199'u (\%29.6) 10. sinıfa, 170'i (\%25.3) 11. sinıfa, 166's (\%24.7) 12. sinıfa devam etmektedir. Öğrencilerin 395'i (\%58.8) k1z ve 277'si (\%41.2) erkektir. Öğrencilerin 137'si (\%20.4) Fen Lisesi'ne, 199'u (\%29.6) Anadolu Lisesi'ne, 170'i (\%25.3) İmam Hatip Lisesi'ne, 166's1 (\%24.7) Mesleki ve Teknik Anadolu Lisesi'ne devam etmektedir. Araştırmada seçkisiz olmayan örnekleme yöntemlerinden 
biri olan amaçsal örnekleme yöntemi kullanılarak araştırma grubu oluşturulmuştur (Büyüköztürk, Çakmak, Akgün, Karadeniz ve Demirel, 2019).

\section{Veri Toplama Araçlan}

Mesleki Karar Envanteri (MKE) (Çakır, 2003): Çakır (2003) tarafından lise 9. sinıfta okuyan 527 öğrenci üzerinden elde edilen verilerle geliştirilen bir ölçektir. Ölçek beşli likert tipi ölçektir ve alınan yüksek puan kararsızlığı ifade ederken, alınan düşük puan ise kararlılığı ifade eder. Ölçeğin yapı geçerliliği için faktör analizi uygulanmıştır. Buna göre; ölçeğin tek boyutlu olup olmadığını anlamak için temel bileşen analizi yapılmış ve ölçek 30 madde olarak belirlenmiş, ölçeğin ilişkisiz alt boyutlarına ayrışıp ayrışmadığını anlamak için varimax dik döndürme tekniği uygulanmış ve ölçek beş boyuta ayrılmıştır. Ölçekteki beş alt boyut, varyansın 40.53'ünü açıklamaktadır. Madde toplam korelasyonu .23 ile .57 arasında değiştiği görülmüştür. Ölçeğin alt boyutları; içsel çatışmalar, kendini yeterince tanımama, meslek ve alan bilgi eksikliği, meslek seçimine ilişkin akılcı olmayan inançlar, dışsal çatışmalardır. Ölçeğin ölçüt geçerliliği; Bacanlı ve Kuzgun tarafından geliştirilen "Mesleki Olgunluk Ölçeği" ile gerçekleştirilmiş ve mesleki kararsılılı yaşayan öğrencilerin mesleki olgunluklarının düşük olduğu gözlenmiştir. Ölçeğin güvenirliliği için; Cronbach Alfa Katsayısı .85 ve ölçeğin test tekrar test uygulaması sonucunda iki ölçüm arasındaki korelasyon katsayısı .83 bulunmuştur (Çakır, 2013).

Kariyer Denetim Odă̆ı Ölçeği (KDOÖ) (Aysan ve Siyez, 2011): Ölçek, kariyer gelişim sürecindeki ergenlerin denetim odaklarını belirlemek için Kuzey İrlanda'da öğrenim gören 743 ergen üzerinde Millar ve Shevlin tarafından 2007'de geliştirilmiştir. Ölçek Aysan ve Siyez (2011) tarafından İzmir ilindeki üç farklı lisede okuyan 490 öğrenci üzerinde Türkçeye uyarlanmıştır. Ölçeğin faktör analizi için Kaiser Meyer Olkin (KMO) değeri 89 olduğu ve ölçeğin toplam varyansın \% 55'ini açıklayan dört faktörlü bir yapısı olduğu görülmüştür. Ölçek içsel denetim, çaresizlik, şans, güçlü diğerleri alt ölçeklerinden oluşmaktadır. Bu alt ölçeklerin yapı geçerliliği için; DFA değerleri sırasıyla GFI=.92, AGFI=.90, CFI=.92, RMSEA=.05, SRMR=.05’ dir. Bu değerler ölçeğin dört faktörlü yapısını doğrular bir düzeyde olduğunu göstermektedir. Ölçek, benzer ölçek geçerliliği için; Nowicki-Strickland Denetim Odağı Ölçeği ile uygulanmış ve Kariyer Denetim Odağı Ölçeğinin içsel denetim, şans, çaresizlik, 
güçlü diğerleri alt ölçeği ile Nowicki-Strickland Denetim Odağı Ölçeği arasindaki korelasyon katsayıları sırayla $.51, .53, .47, .44$ olarak tespit edilmiştir. Ölçeğin güvenirliliği; Sperman Brown Testi Yarılama katsayısı ile bakılmış ve katsayı .82 bulunmuştur. Ölçeğin Cronbach alpa güvenirlilik katsayısı .86 bulunmuştur. Ölçeğin dış denetim boyutu Cronbach alpa katsayısı .89, iç denetim alt boyutunun Cronbach alpa katsayısı .66'dır (Aysan ve Siyez, 2011).

Meslek Seçimine İlişkin Akılcı Olmayan İnançlar Ölçeği (MSİAOİÖ) (Erdem, 2006): Ölçek, “akılcı duygusal davranışçı yaklaşım” temeline dayanır. Ölçek 1955 ortaöğretim öğrencisi üzerinde geliştirilmiştir. Ölçek 33 madde ve 5 alt ölçekten oluşan bir formdur. Alt ölçekler; Mükemmeliyetçilik, Dışsal kontrol, Yanlış çıkarımlar, Genellemeler, Özsaygı'dır. Faktör analizi sonucu ölçek 33 maddeye düşmüş ve yeniden doğrulayıcı faktör analizine bakılmıştr. Buna göre; GFI (.95), CFI (.92), AGFI (.94), RMSEA (.05), RMR (.05) indekslerinin göreceli yüksekliği ölçeğin yapı geçerliliğine bir kanıttır. Ölçeğin, ölçüt geçerliliğini incelek için Nowicki- Strickland Denetim Odağı Ölçeği, Rosenberg Benlik Saygısı Ölçeği ve Akılcı Olmayan İnançlar Ergen Formu ile karşlaştırılmıştır. Ölçeğin bileşen geçerliliği için; ölçek Akılcı Olmayan İnançlar Ergen Formu ile karşılaştııılmış ve anlamlı çıkmıştır (.36, p<.01). Ölçek ayırt ediciliği için; Nowicki-Strickland Denetim Odağı Ölçeği kullanılmış ve sonuç anlamlı çıkmıştır(.28, p<.01). Ölçek Rosenberg Benlik Saygısı Ölçeği ile arasindaki korelasyon $.12(p<.01)$ anlamlı olduğu bulunmuştur. Ölçeğin genel toplam Cronbach Alfa değeri .79'dur. Ölçeğe uygulanan test tekrar test güvenirliliği ise .78' dir (Erdem, 2006).

\section{Veri Analizi}

Araştırmada kullanılan veriler Sakarya'nın Akyazı ilçesindeki dört liseden (Fen Lisesi, Anadolu Lisesi, Mesleki ve Teknik Anadolu Lisesi ve İmam Hatip Lisesi) toplanmıştır. Araştırmada 115 veri eksik ve hatalı görüldügü için analize alınmamış ve değerlendirme 672 veri üzerinden yapılmıştır. Uygulamanın yapılacağı sınıflara araştırmacı tarafından, araştırmanın gerekçeleri belirtilmiş ve ölçekler tanıtılıp nasıl doldurmaları gerektiği anlatılmıştır. Araştırma değişkenleri olan Mesleki Kararsızlık, Kariyer Denetim Odağı, Meslek Seçimine İlişkin Akılcı Olmayan İnançların; cinsiyet değişkenine göre ortalamalar arasında bir fark olup olmadığını belirlemek için Bağımsız Ortalamalar T-Testi, araştırma değişkenleri olan mesleki kararsızlık, kariyer denetim 
odağı alt boyutları, meslek seçimine ilişkin akılcı olmayan inançlar alt boyutları arasındaki ilişkiyi anlamak için Pearson Korelasyon Analizine bakılmıştır. Daha sonra ise; bağımsız değişkenlerin bağımlı değişkeni yordama düzeyini belirlemek için Çoklu Hiyerarşik Regresyon Analizi yapılmıştır.

\section{Bulgular}

Çalışmada verilerin istatistiksel analizleri gerçekleştirilmeden önce, verilerin dağılımında çarpıklık ve basıklık değerlerinin +1 ile -1 aralığında ve sonucunda parametrik analizlere uygun olduğu gözlenmişsir (Seçer, 2017).

\section{Cinsiyete Göre Ölçek Puan Ortalamalanna İlişkin Bulgular}

Tablo 1. Cinsiyete Göre Değişkenlerin Puan Ortalamalarına İlişkin Bağımsız Ortalamalar İçin T-Testi Analizi Sonuçları

\begin{tabular}{|c|c|c|c|c|c|c|c|}
\hline & Kiz & & Erkek & & & & \\
\hline & $\mathrm{N}: 395$ & & $\mathrm{~N}: 227$ & & & & \\
\hline Değişken & $\bar{x}$ & $S$ & $\bar{x}$ & $S$ & $T$ & $D f$ & $P$ \\
\hline MKE & 76.18 & 22.97 & 79.02 & 22.76 & -1.58 & 670 & .11 \\
\hline KDOÖ-İ & 23.86 & 4.15 & 23.07 & 4.81 & 2.28 & 670 & $.02^{*}$ \\
\hline KDOÖ-DD & 31.16 & 10.24 & 36.30 & 12.90 & -5.74 & 670 & $.00^{* *}$ \\
\hline MSİAOIÖ̈ & 83.59 & 12.85 & 91.11 & 13.72 & -7.26 & 670 & $.00^{* *}$ \\
\hline
\end{tabular}

${ }^{*} \mathrm{p}<.05 \quad{ }^{* *} \mathrm{p}<.01$

Tablo 1'e göre, kız öğrencilerin mesleki karar envanteri puan ortalamaları ile erkek öğrencilerin puan ortalamaları arasında anlamlı bir fark olmadığı görülmüştür $\left(t_{(670)}=1.58, p>.05, p=.11\right)$. Kı öğrencilerin iç kariyer denetim odağı toplam puan ortalamaları, erkek öğrencilerin toplam puan ortalamalarından anlamlı düzeyde daha yüksektir $\left(t_{(670)}=2.27, \mathrm{p}<.05, p=.023\right)$. Aynı zamanda kız öğrencilerin dış kariyer denetim odağı toplam puan ortalamaları, erkek öğrencilerin toplam puan ortalamalarından anlamlı düzeyde daha düşüktür $\left(t_{(670)}=-5.74, p<.01, p=.00\right)$. Ayrıca kız öğrencilerin meslek seçimine ilişkin akılcı olmayan inançlar puan ortalamaları erkek öğrencilerden daha düşüktür $\left(t_{(670)}=7.26, \mathrm{p}<.01, p=.00\right)$. 


\section{Değişkenler Arası Korelasyonlar}

Tablo 2. Değişkenlere Ait Pearson Korelasyon Analizi Sonuçlarn

\begin{tabular}{|c|c|c|c|c|c|c|c|c|c|c|}
\hline Değişken & 1 & 2 & 3 & 4 & 5 & 6 & 7 & 8 & 9 & 10 \\
\hline 1. MKE & - & & & & & & & & & \\
\hline 2. KDOÖ-İ & $-.12^{* *}$ & - & & & & & & & & \\
\hline 3. KDOÖ-Ç & $.33^{* *}$ & $-.32^{* *}$ & - & & & & & & & \\
\hline 4. KDOÖ-Ş & $.22^{* *}$ & $-.26^{* *}$ & $.54^{* *}$ & - & & & & & & \\
\hline 5. KDOÖ-GD & $.32^{* *}$ & $-.29^{* *}$ & $.64^{* *}$ & $.50^{* *}$ & - & & & & & \\
\hline 6. MSİAOİÖ-M & $.10^{*}$ & $.34^{* *}$ & -.02 & -.06 & -.05 & - & & & & \\
\hline 7. MSIAOIIÖ-DK & $.44^{* *}$ & $-.26^{* *}$ & $.43^{* *}$ & $.51^{* *}$ & $.50^{* *}$ & $-.09^{*}$ & - & & & \\
\hline 8. MSİAOİÖ-YÇ & $.32^{* *}$ & -.05 & $.28^{* *}$ & $.30^{* *}$ & $.37^{* *}$ & $.13^{* *}$ & $.51^{* *}$ & - & & \\
\hline 9. MSİAOİÖ-G & $.33^{* *}$ & $-.14^{* *}$ & $.35^{* *}$ & $.34^{* *}$ & $.44^{* *}$ & $.11^{* *}$ & $.58^{* *}$ & $.62^{* *}$ & - & \\
\hline 10. MSİAOİÖ-Ö & $.44^{* *}$ & $-.12^{* *}$ & $.33^{* *}$ & $.25^{* *}$ & $.36^{* *}$ & .00 & $.55^{* *}$ & $.42^{* *}$ & $.47^{* *}$ & - \\
\hline
\end{tabular}

${ }^{*} \mathrm{p}<.05 \quad{ }^{* *} \mathrm{p}<.01$

Yordanan değişken mesleki karar verme puanı ile yordayan değişkenler kariyer denetim odağ 1 ve meslek seçimine ilişkin akılcı olmayan inançların alt boyutları arasında anlamlı bir ilişki vardır. Buna göre; mesleki karar envanteri puanı ile kariyer denetim odağı ölçeği alt boyutlanı olan içsellikle zayıf düzeyde negatif ilişki $(r=-.12, p<.01, p=.00)$, çaresizlikle orta düzeyde pozitif ilişki $(r=.33, p<.01, p=.00)$, şansla zayıf düzeyde pozitif ilişki $(r=.22, p<.01$, $p=.00)$, güçlü diğerleriyle orta düzeyde pozitif ilişki olduğu $(r=.32, p<.01$, $p=.00)$ görülmektedir. Mesleki karar envanteri puanı ile meslek seçimine ilişkin akılcı olmayan inançlar ölçeği alt boyutları olan mükemmeliyetçilikle zayıf düzeyde pozitif ilişki ( $r=.10, p<.05, p=.01)$, dışsal kontrolle orta düzeyde pozitif ilişki $(r=.44, p<.01, p=.00)$; yanlış çıkarımlarla orta düzeyde pozitif ilişki $(r=.32, p<.01, p=.00)$; genellemelerle orta düzeyde pozitif ilişki $(r=.33, p<.01$, $p=.00)$; özsaygiyla orta düzeyde pozitif ilişki $(r=.44, p<.01, p=.00)$ olduğu görülmektedir. 


\section{Mesleki Karar Envanterinin Hiyerarşik Regrasyon Analizine İlişkin Bulgular}

Tablo 3. Mesleki Karar Envanteri Puanının Yordanmasına Dair Çoklu Hiyerarşik Regresyon Analizi Sonuçlar

\begin{tabular}{|c|c|c|c|c|c|c|c|c|c|}
\hline Yordayıcı Değişkenler & $R$ & $R^{2}$ & $R^{2}$ Değişikliği $\left(\Delta R^{2}\right)$ & FDeğişikliğip & $B$ & Standart Hata $\left(\mathrm{SH}_{\mathrm{B}}\right)$ & $\beta$ & $t$ & $p$ \\
\hline Standart & & & & & 76.57 & 3.41 & & 22.42 & .00 \\
\hline Adım 1 & .09 & .01 & .01 & .09 & & & & & \\
\hline Cinsiyet & & & & & 2.81 & 1.79 & .06 & 1.57 & .12 \\
\hline Adım 2 & .36 & .13 & .12 & .00 & & & & & \\
\hline KDOÖ-İ & & & & & .01 & .20 & .00 & .04 & .97 \\
\hline KDOÖ-Ç & & & & & 1.05 & .27 & .20 & 3.94 & .00 \\
\hline KDOÖ-Ş & & & & & .13 & .21 & .03 & .63 & .53 \\
\hline KDOÖ-GD & & & & & .95 & .25 & .19 & 3.73 & .00 \\
\hline Adım 3 & .54 & .30 & .16 & .00 & & & & & \\
\hline MSİAOİÖ-M & & & & & .64 & .19 & .12 & 3.39 & .00 \\
\hline MSİAOIÖ-DK & & & & & 1.36 & .26 & .26 & 5.27 & .00 \\
\hline MSİAOİÖ-YÇ & & & & & .28 & .25 & .05 & 1.11 & .25 \\
\hline MSİAOİÖ-G & & & & & -.03 & .23 & -.01 & -.15 & .90 \\
\hline MSİAOİÖ-Ö & & & & & 2.54 & .43 & .24 & 5.94 & .00 \\
\hline$R=.54 R^{2}=.30 \mathrm{~F}=25.13$ & $p=$ & & & & & & & & \\
\hline
\end{tabular}

Adım 1'de cinsiyet değişkeninin ( $\beta=2.81, p>.05, p=.12)$ modele anlamlı bir katkısının olmadığı görülmüştür. Adım 2'de kariyer denetim odağının çaresizlik ( $\beta=.20, p<.01, p=.00)$ ve güçlü diğerleri $(\beta=.19, p<.01, p=.00)$ alt boyutlar1nın mesleki karar verme durumunu anlamlı şekilde yordamaktayken; kariyer denetim odağ içsellik ( $\beta=.00, p>.05, p=.97)$ ve şans $(\beta=.03, p>.05, p=.53)$ alt boyutlarının modele anlamlı katkısının olmadığı görülmektedir. Adım 3 'te sırayla meslek seçimine ilişkin akılcı olmayan inançların mükemmeliyetçilik $(\beta=.12, p<.01, p=.00)$, dişsal kontrol $(\beta=.26, p<.01, p=.00)$ ve özsayg1 $(\beta=.24, p<.01$, $p=.00$ ) alt boyutları mesleki karar envanterini anlamlı şekilde yordamaktadır. Fakat Adım 3'te meslek seçimine ilişkin akılcı olmayan inançların yanlış çı$\operatorname{karmmlar}(\beta=.05, p>.05, p=.27)$ ve genellemeler $(\beta=-.01, p>.05, p=.90)$ alt boyutunun modele anlamlı bir katkısının olmadığı görülmektedir. Bulgular, bağımsız (yordayan) değişkenlerin mesleki karar envanteri puanının toplam varyansın yaklaşık \%30'unu açıklamaktadır.

\section{Tartışma ve Sonuç}

Araştırmanın sonucunda; öğrencilerin mesleki kararsızlıkları cinsiyetlerine göre anlamlı bir farklılık göstermemiştir. Araştırma sonucuna benzer çalı̧̧maların olmasının yanı sıra (Akkoç, 2012b; Çınar, 2011; Watson ve Stead, 
1994) kız öğrencilerin mesleki kararsızlığının erkeklerden az olduğunu (Öztemel, 2012), kız öğrencilerin mesleki kararsızlığının erkeklerden fazla olduğunu (Aydemir, 2017; Bacanll, 2012; Yaman, 2014), ilköğretimde okuyan erkek öğrencilerinin bir yıl içindeki mesleki kararsızlıklarının kızlara göre daha fazla arttığını gösteren (Yazıcıoğlu, 2008) çalışmalar mevcuttur. Yapılan çalışmalardaki bu farklılık; çalışma yapılan grubun yapısından, çalışmanın yapıldığı zaman aralığından, yerleşim yerindeki bireylerin sosyo-kültürel özellik ve sosyo-ekonomik koşullarının farklılığından kaynaklanabileceği düşünülmektedir. Bu nedenle; mesleki kararsızlık üzerinde cinsiyetin etki derecesini anlayabilmek için farklı grup, yer ve zamanda daha fazla çalışma yapılması gerektiği düşünülmektedir.

Kariyer denetim odağında ise, kızların iç kariyer denetim odağının erkeklerden yüksek ve dış kariyer denetim odağının erkeklerden düşük olduğu görülmüştür. Araştırma bulgularına benzer olarak; kız öğrencilerin erkeklere göre daha iç denetimli olduğunu ve ayrıca erkeklerde dış kariyer denetim odağ 1 boyutu olan güçlü diğerleri faktörünün kızlardan daha yüksek olduğunu gösteren çalışmalar mevcuttur (Perry ve diğerleri, 2011; Seymenler ve Siyez, 2016). Araştırma sonucundan farklı olarak, kız öğrencilerin kariyer dış denetiminin erkek öğrencilerden fazla olduğunu (Şeker, 2013); ergen engelli kızların dış kariyer denetim odağının, ergen engelli erkeklere ve engeli olmayan kız ve erkeklere göre daha yüksek olduğunu gösteren çalışmalar mevcuttur (Pham ve Murray, 2019). Ayrıca Hirschi (2010) yaptığı çalışmasında dış denetimli öğrencilerin şansa inandıklarını tespit etmiştir. Araştırma sonuçlarındaki bu farklılığın, araştırma grubunun bireysel ve kültürel özelliklerinden kaynaklanabileceği düşünülmektedir. Günümüzde toplumsal yap1nın değişmesi, kadının sosyal statüsünü ve rolünü de değiştirmiş̧ir. Bu değişim kadının kendine dair bakış açısını da değiştirmiş olabilir. Bu sebeple kadınlar toplumsal yaşamda kendileri ile ilgili oluşan algıları değiştirmeyi, erkeklerden bağımsız olmayı ve para kazanarak güç elde etmeyi istemektedirler (Akkoç, 2012a). Bu yolun kendi ekonomik gücünü elde etmekten geçtiğini bilen kadınlar; iyi bir kazancın, iyi bir eğitimden geçtiğini bildikleri için kendi önlerine sunulan firsatları daha sağlıklı değerlendiriyor olabilirler. Bu sebeple kadınların kariyer iç denetimleri erkeklerden daha yüksek çıkmış olabilir. Türk toplumunda erkek çocuğu soyun devamını sağlayan birey olarak görüldügünden kız çocuklarından daha değerli olarak algılanabilmektedir. Fakat aynı toplum erkek çocuğunu evi geçindirecek kişi olarak gördüğü için 
ondan iyi bir iş sahibi olmasını beklemektedir. Bu çelişki içinde yetişen erkek çocuğunun üzerindeki toplumsal baskı nedeniyle, meslek kararında dış kariyer denetim odaklı olmasına sebep olmuş olabilir.

Kız öğrencilerin meslek seçimine ilişkin akılcı olmayan inançları, erkek öğrencilere göre anlamlı düzeyde daha düşüktür. Araştırma sonucuna benzer sonuçlar vardır (Akkoç, 2012a; Alver ve Kutluca, 2019; Çapan ve Owen, 2018; Gati ve Noa, 2001; Owen ve Çapan, 2017). Araştırma sonucundan farklı olarak Mahadevan (2002) cinsiyet ve kariyer inançları arasında bir ilişki olmadığını belirtirken, Savoly ve Owen (2015) kızların meslek seçimine ilişkin akılcı olmayan inançlarının erkeklerden daha yüksek olduğunu belirtilmektedirler. Ayrıca bazı araştırmacılar, cinsiyetin kariyer inançlarının en önemli yordayıcısı olduğunu belirtirler (Dimakakou ve diğerleri, 2012; Kaur ve Raji, 2017; Özkamalı ve diğerleri, 2014). Türk toplumu toplumsal cinsiyetçi bir yapıya sahip olmakla birlikte günümüzde kadın ve erkeğin eşit görüldüğü bir bakış açısına doğru değişmeye başlamıştır. Günümüz toplumunda kadın, kendi ayaklarının üstünde durabilmek ve kimseye muhtaç olmadan yaşayabilmek için iyi bir kariyer sahibi olmayı istiyor olabilir. Bu bakış açısı da kız öğrencilerinin kendi yeteneklerine ve yeterliliğine olan inancını artırmış ve mesleğini seçme konusunda daha akılcı davranmasına sebep olmuş olabilir. Toplumumuzda erkekler, toplumsal cinsiyetin bir sonucu olarak; kadından daha değerli olduğuna dair bir algıyla yetişmesi, toplumun kendisinden beklentisinin yüksek olması sebebi ile kendilerine dair olumsuz meslek inançları geliştirmiş olabilir.

Değişkenler arasındaki ilişkiye bakıldığı zaman, mesleki kararsızlık ve kariyer denetim odağının içsellik alt boyutu ile zayıf düzeyde negatif ilişki varken çaresizlik, şans, güçlü diğerleri alt boyutları ile zayıf ve orta düzeyde pozitif ilişki olduğu görülmüştür. Araştırma sonucuna benzer bir çalışma olarak; Hirschi ve Valero (2017) şans faktörü ve kariyer kararı arasında pozitif yönde bir ilişki bulmuştur. Literatürde araştırma sonucundan farklı olarak; Şahin ve diğerleri (2015), mesleki kararsızlık ile kontrol odağının alt boyutu olan "şans" arasında zayıf düzeyde negatif ilişki olduğunu ve "çabanın anlamsızlığı" alt boyutu ile arasında düşük düzeyde pozitif ilişki olduğunu bulmuşlardır. Bazı bireyler, kendini bir mesleğe götürecek yolda ilerlerken ailesi, öğretmenleri ve eğitime yön veren otoriteler tarafından gerekli şekilde destek görememektedir. Bu durum bireyin kendini yeterince tanıyamamasına ve 
kendi yeterliliklerinin farkına varamamasına sebep olmaktadır. Bu nedenlerle birey bir meslek kararı verme zorunluluğu ile karşı karşıya kaldığında meslek seçimi konusunda kendini çaresiz, şansız ve desteksiz hissediyor olabilir. Mesleki kararsızlık değişkeni ve meslek seçimine ilişkin akılcı olmayan inançlar değişkeninin alt boyutları olan mükemmeliyetçilik, dışsal kontrol, yanlış çıkarımlar, genellemeler, özsaygı arasında zayıf ve orta düzeyde pozitif bir ilişki olduğu görülmüştür. Literatürde bu araştırmayı destekleyecek bir çalışmaya rastlanmamıştır. Öğrenciler meslek seçim zorunluluğu doğduğunda ve bu konuda kararsız kaldığında sorununu akılcı bir biçimde çözme yöntemini bilmiyor olabilirler.

Araştırma sonuçları, bağımsız (yordayan) değişkenlerin mesleki karar verme puanına ilişkin toplam varyansın yaklaşı \%30'unu açıkladığını göstermektedir. Araştırmada cinsiyet değişkeninin mesleki kararsızlıkla anlamlı bir ilişkisinin olmadığı ve modele anlamlı bir katkısı olmadığı bulunmuştur. Araştırma sonucu ile benzer bir çalışma bulunmamıştır. Kariyer denetim odağının alt boyutları olan; çaresizlik ve güçlü diğerleri değişkenleri mesleki karar envanteri puanının anlamlı yordayıcılarıdır. Literatürde benzer bir çalışmaya ratlanmamıştır. Eğitimde fırsat eşitliği, bireylerin seçtikleri mesleğin onlara iş güvencesi sunup sunmayacağı ile ilgili belirsizlik, ebeveynlerin çocuklarına karşı tutumları, eğitim sisteminin akademik başarı odaklı olması gibi sebepler bireylerin kariyer seçiminde kararsızlık yaşamasına sebep olmuş olabilir. Ayrıca kariyer denetim odağı ölçeğinin içsellik ve şans alt boyutunun modele anlamlı bir katkısının olmadığı bulunmuştur. Literatürde dış denetimli bireylerin şansa inandıklarını, ayrıca bireylerin lise ve mesleğe geçişte şansa inandıklarını gösteren (Hirschi, 2010), mesleki kararsızlık ile kontrol odağının alt boyutu olan "şans" ile zayıf düzeyde negatif anlamlı ilişki olduğunu gösteren (Şahin ve diğerleri, 2015), şans ile kariyer kararı arasında doğrusal ilişki olduğunu gösteren (Hirschi ve Valero, 2017) bulgular mevcuttur.

Meslek seçimine ilişkin akılcı olmayan inançların alt boyutları olan mükemmeliyetçilik, dışsal kontrol ve özsaygı mesleki kararsızlığın anlamlı yordayıcılarıdır. Literatürde araştırma ile benzerlik gösteren çalışmalara rastlanmıştır. Elliott (1995) akılcı olmayan kariyer inançlarının kişide kendine güvensizlik, düşük özsaygı, kararsızlık, istenilmeyen meslek seçimi ile sonuçlandığını; Bacanlı (2012) meslek seçimine ilişkin akılcı olmayan inançların alt 
boyutlarından biri olan dışsal kontrolün mesleki karar verme güçlüklerini anlamlı şekilde yordadığını belirtir. Eliott (1995) meslek seçimi etkileyen en önemli faktörün bireyin çevresi tarafından şekillendirilen, içsel eleştiriler (meli/ -malı) dediğimiz kişide zorunluluk anlatan ifadeler olduğunu belirtir. Bu zorunluluk ifadeleri bireyde mükemmel bir meslek seçimi yapması gerektiği ile ilgili akılcı olmayan inanç geliştirmesine ve bireyin mesleki kararsızlık yaşamasına sebep olabilir. Ayrıca -meli/-malı düşünce tarzı bireyin kendi yeterliliğini sorgulamasına sebep olacağından meslek seçiminde kararsızlık yaşayabilir.

Araştırma bulguları genel olarak değerlendirildiğinde, mesleki kararsızlık üzerinde, kariyer denetim odağı ile meslek seçimine ilişkin akılcı olmayan inançların önemi ortaya çıkmaktadır. Ergenlik döneminde mesleki gelişim önemli bir yeterlik alanıdır. Öğrencilerin mesleki gelişimlerine katkı sağlayacak, bireysel ve gurupla rehberlik ve psikolojik danışma hizmetlerinin sağlanması alan çalışanlarından beklenmektedir (Milli Eğitim Bakanlığı, 2020). Bu doğrultuda öğrencilerin mesleki gelişimlerine katkı sağlayacak etkinlikler öğrencilere, öğretmenlere ve ebeveynlere yönelik düzenlenebilir. Yapılan çalışma sınırlı ve belli kültüre sahip olan bir çevrede yapılmıştır. Bu sebeple insan hayatında büyük öneme sahip meslek seçim kararını etkilediği düşünülen kariyer denetim odağı ve meslek seçimine ilişkin akılcı olmayan inançlar değişkenleri farklı çevre koşullarında yeniden araştırılarak bu değişkenlerin mesleki kararsızlığa etkisinin olup olmadığ incelenmelidir. Kariyer denetim odağı ve meslek seçimine ilişkin akılcı olmayan inançların mesleki kararsızlık üzerindeki etkisi göz önüne alındığında öğrencilerin kararsızlıklarını gidermek için deneysel çalışmalar yapılarak grup rehberliği programı geliştirilebilir. 
EXTENDED ABSTRACT

\title{
The Role of Career Locus of Control and Irrational Beliefs About Career Choice in Explaining the Career Indecision of High School Students
}

\author{
Niğmet Yılmaz - Ahmet Bedel \\ Ministry of National Education- Maltepe University
}

One of the important developmental tasks of the adolescence period, which has an important place in human life, is the choice of career. Adolescence period; is a period when individuals have a clearer idea about professions and make choices among career alternatives (Siyez, 2019). In this period, if individuals cannot choose a suitable profession for themselves while they should choose their profession, if they change their decisions frequently and cannot make a decision, in this situation this can be concluded as that individual is experiencing professional indecision (Kuzgun, 2017). Individuals want to understand which of the consequences of their behavior comes from themselves and which from outside (Şeker, 2013). If individuals think that the results of career choice action are under their own control, they have an internal career locus of control, and if the individual thinks that the consequences of their actions related to their career choice are factors other than themselves (helplessness, luck, powerful others), they have an external career control (Millar and Shevlin, 2007). If individuals think that their future career success comes from themselves, they pass the professional decisionmaking process in a healthier way (Millar and Shevlin, 2007). At the same time to understand the professional decision-making skills of individuals; it is necessary to know how their perceptions are formed, how they make their career decisions and how they apply them (Amudson, 1995). The belief system of individuals affects their career choices as well as their life. Irrational beliefs on profession are the thoughts that prevent people from actualizing their career goals (Corbishley and Yost, 1989). These thoughts can prevent the individual from making the right decision. Since the high school period is a period when professional decisions are made; it is thought that 
determining the factors that are thought to have an effect on the ambivalence of the students' career choice with the conducted research, will contribute to the career counseling services to be offered to the students. In line with these explanations, the purpose of the study is to determine whether the professional indecision of high school students, career control centers (internal and external locus of control) and irrational beliefs about career choice differ according to their gender, to examine the relationship between these variables, to determine to what extent career control centers and irrational beliefs about career choice predict vocational indecision.

Relational scanning model, which is a subgroup of general survey model, was used in the study. The study group consists of 672 secondary education students studying in Akyaz1 district of Sakarya in the 2018-2019 academic year. The research group was formed by using purposeful sampling method. Career Decision Inventory, Career Locus of Control Scale (CLCS), and Irrational Beliefs in Career Choices of High School Students (SIBCC-HS) were used in the study. Descriptive statistics, Independent Samples T-test, Pearson Product-Moment Correlation, Hierarchical Linear Regression Analysis were used in the study.

According to the results of the research; the occupational indecision of the students did not differ by gender. It was observed that girls had higher internal career locus of control than boys and lower external career locus of control than boys. Irrational beliefs of female students about career choice are lower than male students. It was seen that the gender variable did not have a significant relationship with vocational indecision and did not make a significant contribution to the research model. The sub-dimensions of career locus of control; helplessness and powerful others are significant predictors of vocational indecision. Sub-dimensions of irrational beliefs about career choice; which are perfectionism, external control, and self-esteem, were found to be significant predictors of professional indecision. The research results show that the predictive variables explain about $30 \%$ of the total variance regarding the professional decision making score.

According to the results of the study, there was no difference in the levels of professional indecision between males and females. This situation may have resulted from the structure of the study group, the working time period, and the socio-cultural and socio-economic conditions of the settle- 
ment. In career locus of control, it was observed that girls had higher internal career locus of control than boys and lower than boys. Changes in the social structure may indicate that female students are affected by more internal factors in their choice of profession, while males are affected by more external factors. Irrational beliefs about the career choice of female students are significantly lower than male students. Nowadays, women are struggling to stand on their own feet and to be independent. It is thought that this attitude of the woman is to cause her to know herself and to be aware of her competencies and therefore to adopt more rational beliefs in her career choice. According to the results of the research, independent (predictor) variables explain approximately $30 \%$ of the total variance regarding the professional decision making score. Equal opportunities in education, uncertainty about whether the profession that individuals choose will provide them with job security or not, attitudes of parents towards their children, and the academic success-oriented education system may have caused individuals to be indecisive in their career choice. In addition, the expressions of necessity within irrational beliefs may cause the individual to develop an irrational belief about the need to make a perfect career choice and to experience professional indecision. When the findings of the study are evaluated in general, the importance of career locus of control and irrational beliefs about career choice emerges on professional indecision. Professional development during adolescence is an important area of competence. Providing individual and group guidance and psychological counseling services that will contribute to the professional development of students is expected from field professionals (Ministry of National Education, 2020). Accordingly, activities that will contribute to the professional development of students can be organized for students, teachers and parents. The study was conducted in a limited and culturally spesific environment. For this reason, variables of career locus of control and irrational beliefs about career choice which are thought to have a great importance on vocational decision, which has great importance in human life, should be re-investigated in different environmental conditions and whether these variables affect occupational indecision should be investigated. Considering the effect of irrational beliefs on career locus of control and career choice on professional indecision, a group guidance program can be developed by conducting experimental studies to eliminate students' indecision. 


\section{Kaynakça / References}

Akın, Ü. (2014). Akılcı duygusal davranışçı terapi. A. Akın., ve R. Şahin (Ed.). Psikolojik danışma kuramlar içinde (s.257). İstanbul: Lisans Yayıncılık.

Akkoç, F. F. (2012a). Lise öğrencilerinin mesleki kararsızlıklarının sosyo-demografik faktörlere göre incelenmesi. Mehmet Akif Ersoy Üniversitesi Ĕ̆itim Fakültesi Dergisi, 23(1), 215-233.

Akkoç, F. F. (2012b). Lise öğrencilerinin mesleki kararsızlıkları kariyer inançları arasindaki ilişki. Buca Eğitim Fakültesi Dergisi, 32, 49-70.

Alkal, A., Korkmaz, O. ve Akça, M. Ş. (2018, Nisan). Lise öğrencilerinde mesleki kararsızlık: Lise türüne göre karşılaştırılması ve yaşam amaçları ve pozitiflik düzeyleri ile ilişkisinin incelenmesi (Öz). III. INES International Education and Social Science Congress sunulan bildiri (s. 227), Antalya, Türkiye. Erişim Adresi: https://books.incescongress.com/dl/ESS-2018-Abstracts-book.pdf

Alver, B. ve Kutluca, V. (2019, Haziran). Lise son sınıf öğrencilerinin meslek seçimindeki akılcı olmayan inançlarının incelenmesi: Kırıkkale il örneği. VI. International Eurasian Educational Research Congress sunulan bildiri içinde (s. 38-48), Ankara, Türkiye. https://ejer2019.ejercongress.org adresinden erişilmiştir.

Amundson, N. E. (1995). An interactive model of career decisionmaking. Journal of Employment Counseling, 32(1), 11-21.

Arulmani, G., Laar, D. V., ve Easton, S. ( 2003). The influence of career beliefs and socio-economic status on the career decision-making of high school students in India, International Journal for Educational and Vocational Guidance, 3(3), 193204.

Aydemir, L. (2017). Lise öğrencilerinin meslek seçimlerindeki kararsızlıklarına etki eden faktörler: Trabzon örneği. Sosyal Bilimler Enstitüsü Dergisi, 10, 641-654.

Aysan, F., ve Siyez, D. M. (2011). Kariyer denetim odağı ölçeği'nin Türkçe geçerlik ve güvenirlik çalışması. XI. Ulusal Psikolojik Danışma Rehberlik Kongresi, İzmir.

Bacanlı, F. (2012). Kariyer kararı verme güçlükleri ve meslek seçimine ilişkin akılcı olmayan inançların ilişkisi. Türk Psikolojik Rehberlik ve Danışma Dergisi, 4(37), 86-95.

Bingöl, O. (2014). Toplumsal cinsiyet olgusu ve Türkiye'de kadınlı. KMÜ Sosyal ve Ekonomik Araştırmalar Dergisi, 16(1),108-114.

Büyüköztürk, Ş., Çakmak, E. K., Akgün, Ö. E., Karadeniz, Ş. ve Demirel, F. (2019). Ĕ̆itimde bilimsel araştırma yöntemleri (25. Baskı). Ankara: Pegem Akademi.

Corbıshley, M. A., ve Yost, E. B. (1989). Assessment and tretment dysfunctional cognitions in career counseling. Career Planning and Adult Development Journal, 5, 20-26. 
Çakır, M. A. (2003). Bir mesleki grup rehberliği programmmn lise öğrencilerinin mesleki kararsıllk düzeylerine etkisi. Yayınlanmamış Doktora Tezi, Ankara Üniversitesi, Ankara.

Çapan, B. E., ve Owen, F. K. (2018). Ortaöğretim öğrencilerinin meslek seçimine ilişkin akılcı olmayan düşünceleri. Mehmet Akif Ersoy Üniversitesi Ĕ̆itim Fakültesi Dergisi, 47, 360-386.

Çapçı, G. (2017). Kontrol odağı düzeyinin mesleki kararlilığa etkisi: Lise öğrencileri üzerinde bir araştırma. Yayınlanmamış Yüksek Lisans Tezi, Bahçeşehir Üniversitesi, İstanbul.

Çınar, Ç. (2011). Lise son sinnf öğrencilerinin meslek seçimi kararlarnnda benlik algisının önem. Yayınlanmamış Yüksek Lisans Tezi, Maltepe Üniversitesi, İstanbul.

Dimakakou, D. S., Argyropoulou, K., Drosos, N., ve Terzaki, M. (2012). Career beliefs of Greek and Non-Greek vocational education students. Creative Education, 3(7), 1241-1250.

Elliott, K. J. (1995). Anthetic dialogue: A new method for working with dysfunctional beliefs in career counseling. Journal of Career Development, 22(2), 141-148.

Enright, M. S. (1996). The relationship between disability status, career beliefs and career indecision. Rehabilitation Counseling Bullettin, 40(2), 134-152.

Erdem, A. Y. (2006). Lise öğrencileri için meslek seçimine ilişkin aklcı olmayan inançlar ölçeğinin geliştirilmesi. Yayınlanmamış Yüksek Lisans Tezi, Hacettepe Üniversitesi, Ankara.

Gati, I., ve Noa, S. (2001). High school students career related decisionmaking difficulties. Journal of Counseling and Development, 79(3), 331-341.

Guan, Y., Wang, Z., Dong, Z., Liu, Y., Yeu, Y., Liu, H., Zhang, Y., Zhou, W., ve Liu, H. (2012). Career locus of control and career success among Chinese Employess: A multidimensional approach. Journal of Career Assessment, 21(2), 295-310.

Hamamcı, Z., ve Çoban, A.E. (2007). Mesleki olgunluk ve mesleki kararsızlığın akılcı olmayan inançlarla ilişkisi. Türk Psikolojik Danışma ve Rehberlik Dergisi, 27(3), 32-40.

Hamamc1, Z., ve Hamurlu, M. K. (2005). Anne babaların meslek gelişimine yardımcı olmaya yönelik tutumları ve bilgi düzeylerinin çocuklarının mesleki kararsızlıkları ile ilişkisi. İnönü Üniversitesi Eğitim Fakültesi Dergisi, 6(10), 55-69.

Hartman, B.W. Fuqua, D.R., ve Hartman, P.T. (1983). The predictive potential of the career decision scala in identifying cronic career indecision. The Vocational Guidance Quraterly, 32(2), 103-108. 
Hechtlinger, S., Levin, N. ve Gati, I. (2017). Dysfunctional career decision-making beliefs: A multidimensional model and measure. Journal of Career Assessment, 27(2).

Herring, T. L. (1990). Attacking career myths among native Americans: İmplications for counseling. School Counselor, 38(1), 13-19.

Hirschi, A. (2010), The role of chance events in th school-to-work transition: The influence of demographic, personality and career development variables. Journal of Vocational Behavior, 77(1), 39-49.

Hirschi, A., ve Valero, D. (2017). Chance events and career decidedness: Latent profiles in relation to work motivation. The Career Development Quarterly, 65(1), 215.

Kantaş, Ö., Güldü, Ö., ve Kart, M. E. (2018), Career locus and career adaptabilities: A self-determination perspective for Turkish University Students case. Sosyal Güvenlik Dergisi, 8(1), 215-234.

Karasar, N. (2016). Bilimsel araştırma yöntemleri. Ankara: Nobel Yayıncllk.

Kaur, S., ve Raji, N. S. (2017). Career beliefs of adolescents in relation to their family environment. International Research Journal of Commerce Arts and Science, 8(5), 220-233.

Kelly, K. R., ve Lee, W.C. (2000). Mapping the domain of career decision problems. Journal of Vocational Behaviour, 61(2), 302-326.

Kepir, D. D. (2011). Üniversite adaylarnda meslek seçimine ilişkin akılcı olmayan inançlar, mesleki olgunluk ve umut düzeyleri. Yayınlanmamış Yüksek Lisans Tezi, Hacettepe Üniversitesi, Ankara.

Kurdök, O. (2010). Bilişsel bilgiyi işleme yaklaşımma göre geliştirilen mesleki karar verme programının sınanması. Yayınlanmamış Doktora Tezi, Çukurova Üniversitesi, Adana.

Kurdök, O., ve Kayadibi, S. (2018). Personality traits as a predictor of career indecision of high school students. Journal of Strategic Research in Social Science, 4(1), 8090.

Kim, M., ve Kim, S. (2017). The effect of career preparation program on self-leadership and career locus of control among university students in Korea. Journal of The Korea Academia-Industrial, 18(11), 399-408.

Kocadağ, M. (2019). Elektronik sporla ilgilenen ergenlerin mesleki karar düzeylerinin çeşitli değişkenler açısından incelenmesi. Yayınlanmamış Yüksek Lisans Tezi, Uludağ Üniversitesi, Bursa.

Kuzgun Y., ve Bacanli F. (2011). Rehberlik ve psikolojik damışmada kullannlan ölçekler. Ankara: Nobel Yayinclik. 
Kuzgun, Y. (2017). Meslek gelişimi ve danışmanlı̆̆̆. Ankara: Nobel Yayıncllk.

Ladany, N., Melıncoff, D. S., Constantine, MG., ve Love, R. (1997). At-risk urban high school students commitment to career choices. Journal of Counseling Development, 76(1), 45-52.

Lewis, R. A., ve Gilhausen, M. N. (1981). Myths of career development: A cognitive approach of career counseling. Personnel and Guidance Journal, 59, 296-299.

Liphits-Braziler, Y., Tatar, M., \& Gati, I. (2017). Strategies for coping with career indecision: Concurrent and predictive validity. Journal of Vocational Behavior, 91, 170-179.

Mahadevan, L. (2002). Acculturation and career beliefs is there a relationship for international university students. College Student Journal, 44(3), 633-658.

McAuliffe, G. J. (1991). Assessing and treating barriers to decision making in career classes. The Career Development Quarterly, 40, 82-92.

Millar, R., ve Shevlin, M. (2007). The development and factor structure of a career locus of control scale for use with school pupils. Journal of Career Development, 33, 224-249.

Rehberlik ve psikolojik danışma hizmetleri yönetmeliği. (Ağustos 14, 2020). Resmi Gazete. Sayı: 31213. https://www.resmigazete.gov.tr/eskiler/2020/08/202008142.htm adresinden erişilmiştir.

Owen, F. K., ve Çapan, B. E. (2017). Fen, teknoloji, matematik ve mühendislik alanların seçmeyi planlama: Meslek seçimine ilişkin inançlar. Hacettepe Üniversitesi Ĕ̆itim Fakültesi Dergisi, 33(4), 915-933.

Özkamall, E., Cesuroğlu, Ş. G., Hamamcı, Z., Buğa, A., ve Çekiç, A. (2014). The investigation of relationships between vocational maturity and irrational career beliefs. Procedia-Social and Behavioral Sciences, 116, 3072-3074.

Öztemel, K. (2012). Kariyer kararsızlı̆̆ ile mesleki karar verme öz yetkinlik ve kontrol odağı arasındaki ilişkiler. GEFAD/ GUJGEF, 32(2), 459-477.

Özyürek, R. (2012). Sosyal-bilişsel yaklaşımlar. B.Yeşilyaprak (Ed.). Mesleki rehberlik ve kariyer danışmanlı̆̆ içinde (s. 221-261). Ankara: PEGEM Yayıncllk.

Peng, H., ve Herr, E.L. (2000). Evaluation of a distance education course in students' decision-making and beliefs about careers. Psychological Reports, 87(3), 12181228.

Perry, J. C., Liu, X., ve Griffin, G. C. (2011). The career locus of control scale for adolescents: Further evidence of validity in the United States. Journal of Career Development, 38(2), 167-185. 
Pham, Y. K., ve Murray, C. (2019). Career locus of control and school-and career-related adjustment among high-need youth with and without disabilities. Journal of Career Development, 46(5), 502-515.

Santrock, J. W. (2012). Ergenlik (Çev.ed. D. M. Siyez). Ankara: Nobel yayın.

Savoly, D. K., ve Owen, F. K. (2015). Üniversite adaylarında meslek seçimine ilişkin akılcı olmayan inançlar. International Journal of Human Sciences, 12(2), 821-836.

Seçer, İ. (2017). SPSS ve LISREL ile pratik veri analizi ve raporlaştırma. Ankara: Anı Yayincilik.

Seymenler, S., veSiyez, D. M. (2016). Lise öğrencilerinde kariyer denetim odağını yordayıcı değişkenler olarak toplumsal cinsiyet ve ebeveyne bağlanma. Ĕ̈gitim ve Öğretim Araştırmalarn Dergisi, 5(4), 286-300.

Schnorr, D., e Ware, H. W. (2001). Moving beyond a deficit model to describe and promote the career development of at-risk youth. Journal of Career Development, 27(4), 247- 263.

Siyez, D. M. (2019). Gelişimsel yaklaşımlar. B.Yeşilyaprak (Ed.), Mesleki rehberlik ve kariyer danışmanlı̆̆ içinde (s. 191). Ankara: PEGEM Yayıncllk.

Şahin, M., Sarı, S. V., Duman, S., Kerimoğlu, U., ve Kocaman, T. (2015). Mesleki kararsızlığın yordanmasında kontrol odağı ve mantık dışı inançların rolü. Türk Psikolojik Danışma ve Rehberlik Dergisi, 5(43), 11-20.

Şeker, G. (2013). Lise öğrencilerinde meslek kararı verme yetkinliği ve kariyer denetim odağınin incelenmesi. Yayınlanmamış Yüksek Lisans Tezi, Ankara Üniversitesi, Ankara.

Şeker, G., ve Kaya, A. (2019). Mesleki karar verme programının onuncu sınıf öğrencilerinin mesleki kararsızık düzeyleri üzerinde etkiliğinin sınanması. Gazi Üniversitesi Ĕ̈̆itim Fakültesi Dergisi, 39(1), 457-476.

Ulu, E. (2007) Lise öğrencilerinin kariyer inançlarnnı bazı değişkenlere göre yordanması Yayınlanmamış Yüksek Lisans Tezi, Ege Üniversitesi, İzmir.

Walsh, B. D., ve Thompson, B. (1995). The construct validity of scores on the career beliefa inventory. Paper Presented at the Anual Meeting of the Mid-South Educational Research Association, Biloxi.

Watson, M. B., ve Stead, G. B.(1994). Longitual study of career decidedness among white South African High School Students. Journal of Vocational Behaviour, 45(3), 261-269.

$\mathrm{Xu}, \mathrm{H}$. , ve Bhang, C. H. (2019). The structure and measurement of career indecision: A critical review. The Career Development Quarterly, 67(1), 2-20. 
Xu, H., ve Tracey, T. J. G. (2014). Ambiguity tolerance with career indecision: An examination of the mediation effect of career decision-making self-efficacy. Journal of Career Assessment, 23(4), 519-532.

Yaman, D. Y. (2014). A study on career indecision of 11th and 12th grade students: Testing gender, career beliefs, academic self-efficacy and problem solving skills through path analysis. Yayınlanmamış Doktora Tezi, Ortadoğu Üniversitesi, Ankara.

Yazıcığlu, A. (2008). İlköğretim sekizinci smnf öğrencilerinin mesleki karar düzeylerinin incelenmesi: Uzunlamasina bir çalışma. Yayınlanmamış Yüksek Lisans Tezi, Afyon Kocatepe Üniversitesi, Afyon.

Yllmaz, N. F., ve Gündüz, Ç. H. (2018). Career indecision and career anxiety in high school students: An investigation through structual equation modelling. Eurasian Journal of Educational Research, 78, 23-42.

\section{Kaynakça Bilgisi / Citation Information}

Yılmaz, N. ve Bedel, A. (2021). Lise öğrencilerinin mesleki kararsızlıklarını açıklamada kariyer denetim odağı ile meslek seçimine ilişkin akılcı olmayan inançların rolü. OPUS-Uluslararası Toplum Araştırmalarn Dergisi, 17(34), 1023-1046. DOI: 10.26466/opus.800873 